\title{
Cigarette smoke extract induces differential expression levels of beta-defensin peptides in human alveolar epithelial cells
}

\author{
Tony Pierson ${ }^{1}$, Sarah Learmonth-Pierson ${ }^{1}$, Daniel Pinto ${ }^{1}$ and Monique $L$ van Hoek ${ }^{1,2,3^{*}}$
}

\begin{abstract}
Background: The damaging effects of cigarette smoke on the lungs are well known in terms of cancer risks. Additional molecular changes within the lung tissue can also occur as a result of exposure to cigarette smoke. The human $\beta$-defensin (hBD) class of antimicrobial peptides is the focus of our research. In addition to antimicrobial activity, $\beta$-defensins also have immunomodulatory functions. Over 30 previously unrecognized $\beta$-defensin genes have recently been identified in the human genome, many with yet to be determined functions. We postulated that altered $\beta$-defensin production may play a role in the pathogenesis observed in the lungs of smokers. Our hypothesis is that cigarette smoke exposure will affect the expression of $\beta$-defensins in human lung alveolar epithelial cells (A549).

Methods: We exposed A549 cells to cigarette smoke extract (CSE) and measured the changes in mRNA levels of several antimicrobial peptides by quantitative real-time PCR, and directly observed peptide expression in cells by immunofluorescence (IF) microscopy.

Results: We found that hBD3, hBD5, and hBD9 gene expression was upregulated in A549 cells exposed to CSE. HBD1, hBD8, hBD18 and LL-37 gene expression did not significantly change upon exposure to CSE. Expression of hBD3 and hBD4 peptides was visualized by IF.

Conclusions: This differential expression suggests that hBD3, hBD5, and hBD9 may play a role in the changes to the lung tissue observed in smokers. Establishing differential $\beta$-defensin expression following CSE treatment will add to our understanding of the molecular response of the lung alveolar epithelium to cigarette smoke exposure.
\end{abstract}

Keywords: Cigarette smoke extract, $\beta$-defensins, Lung, Alveolar epithelial cells, Antimicrobial peptide

\section{Background}

Smoking cigarettes increases the risk of contracting lung cancer [1]. Lung cancer caused an estimated 159,300 deaths in the United States in 2009, and is the leading cause of cancer related mortality [2]. In addition to causing cancer, smoking increases the risk of dying prematurely due to chronic obstructive pulmonary disease (COPD) or emphysema [3], stroke and cardiac arrest [4]. Cigarette smoke contains thousands of chemical components, many of which are capable of acting as either carcinogens [5] or

\footnotetext{
* Correspondence: mvanhoek@gmu.edu

'School of Systems Biology, George Mason University, Manassas, VA, USA ${ }^{2}$ National Center for Biodefense and Infectious Diseases, George Mason University, Manassas, VA, USA

Full list of author information is available at the end of the article
}

foreign antigens [6-8]. Once inhaled, some cigarette smoke components adhere to cells lining the respiratory tract, triggering a robust response by lung cells, including activating the innate immune system [9].

Antimicrobial Peptides (AMPs) are small (<100 amino acids) peptides that play a critical role in host airway defense as part of the innate immune system [10]. $\alpha$ and $\beta$ are the two major classes of defensin AMPs. $\beta$-defensin expression is associated with some chronic lung diseases, including COPD [11-14]. In addition to $\alpha$ and $\beta$ defensins, humans possess one member of the cathelicidin class of AMP, LL-37, which was also assessed in these experiments. $\alpha$-defensins are not expressed in epithelial cells, and were not measured in the present study.

\section{Biomed Central}


The Human Lung Alveolar Epithelial (A549) cell line is a model system used to model alveolar epithelial type II cells (ATII). We used this model for the quantification of relative AMP expression levels after exposure to bacteria [15]. Although this model has been extensively used in the literature, the limitation of this model is that it does not undergo differentiation to express the alveolar type I (ATI) phenotype [16]. Given the specific goal of this experiment, we determined that the A549 model was an appropriate tool for our study. In this experiment we tested mRNA level changes in response to exposure to cigarette-smoke extract (CSE) of known as well as recently identified $\beta$-defensin genes [17-20].

Until recently, only four human $\beta$-defensins (hBDs) were known to be expressed in respiratory epithelial cells (hBD1, hBD2, hBD3 and hBD4) [21-23]. However, recent computational and genomic research has predicted over 30 additional human $\beta$-defensins, many of which have not been investigated for their biological function $[17,24]$. Importantly, defensin peptides appear to play multiple roles in vivo and exhibit an immunomodulatory function, similar to cytokines or chemokines. Expression of $\beta$-defensins can be induced via NF- $\mathrm{B}$ activation mainly through TLR receptor binding to microbial components, or via pro-inflammatory cytokines, such as TNF- $\alpha$ and IL1- $\beta$. Weinberg characterized $\beta$-defensins as complex molecules whose proper function is critical for effective immune system function and that when $\beta$-defensin production is altered, especially in areas where cells are already not functioning properly, AMP expression may actually increase disease progression [25]. In addition to the pathological changes observed in lungs exposed to smoke, exposed bronchial epithelial cells secrete many cytokines with the ability to stimulate immune cell migration [26]. $\beta$-defensin expression may also produce a cellular environment where inflammation is enhanced [25] and vascular permeability is increased [27].

Recent publications have shown that exposure of cells to cigarette smoke represses the induction of hBD2 expression by cells exposed to the bacterial lipopolysaccharide $[28,29]$. Human gingival epithelial cells exposed to cigarette smoke show increased expression of several $\beta$-defensins as well as proinflammatory cytokines [30]. Cigarette smoke directly or indirectly alters the expression of hBD2 [31]. It has also been suggested that this peptide may play a role in the pathogenic effects caused by cigarette smoke [20]. Our hypothesis is that exposure of Human Alveolar Epithelial Cells (A549) to cigarette smoke will lead to measurable changes in gene expression levels for some of the newly-identified human $\beta$-defensin peptides (hBDs) as measured by quantitative real-time PCR (qRT-PCR). Our finding that exposure to cigarette smoke increases certain $\beta$-defensin gene expression would suggest that repeated exposure with each new cigarette would lead to chronic over-expression of those $\beta$-defensins and possibly exacerbate the deleterious effects of cigarette smoke-damaged cells.

\section{Materials and methods \\ $\beta$-defensin Induction in A549 cells}

Low passage human lung epithelial cell line (A549, ATCC CCL-185) were grown to 95\% confluence in 6 well culture plates $\left(1 \times 10^{6}\right.$ cells per well, BD catalog \# 353046) with Ham's F-12 (Cellgro 10-080-CV) containing $10 \%$ heat inactivated fetal bovine serum, $37^{\circ} \mathrm{C}$, $5 \% \mathrm{CO}_{2}$. Cells were then washed with PBS and fed serum-free Hams F-12 media overnight. Following the previously established protocol [5,31], cells were exposed to either $50 \mu \mathrm{g} / \mathrm{ml}$ of the $40 \mathrm{mg} / \mathrm{ml}$ stock solution of cigarette smoke extract (CSE in 100\% DMSO) in Ham's F-12 media, or an equivalent amount of DMSO alone in Ham's F-12 media, or $10 \mathrm{ng} / \mathrm{ml}$ of IL-1 $\beta$ (Sigma) in Ham's F-12 media, for 30 minutes.

\section{Cigarette Smoke Extract (CSE)/Cigarette smoke condensate (CSC)}

CSE was purchased from Murty Pharmaceuticals, Lexington KY [5,31]. According to the manufacturer CSE was produced by burning one University of Kentucky "1R13" cigarette and extracting the total particulate into $100 \%$ DMSO to prepare a $40 \mathrm{mg} / \mathrm{ml}$ stock solution. Cells were exposed to $50 \mu \mathrm{g} / \mathrm{ml}$ of the $40 \mathrm{mg} / \mathrm{ml}$ stock solution of cigarette smoke extract (CSE in 100\% DMSO) suspended in Ham's F-12 media. The control cells received the equivalent volume of DMSO devoid of CSE suspended in Ham's F-12 media. Previously published reports using this material were followed $[5,31]$.

\section{Analysis of AMP gene expression by quantitative reverse transcription qRT-PCR}

After exposure, cells were harvested, mRNA, extracted, and cDNA made following our previously published protocol for qRT-PCR of antimicrobial peptides [15,32]. Quantitative RT-PCR was performed with primers specific for the following $\beta$-defensin peptides: hBD1, hBD3, hBD5, hBD6, hBD8, hBD9, hBD18, and the cathelicidin LL-37 in order to measure how much each gene was activated or inhibited by the cigarette smoke treatment. Control cells were used as a baseline to compare induction of gene expression in cells exposed to cigarette smoke extract, and levels of $18 \mathrm{~S}$ rRNA were used to normalize between samples, leading to the relative units of expression indicated for each experiment. Using a previously established protocol [15,32], quantitative real-time PCR analysis in a MyiQ Single Color Real-Time PCR Detection System (BioRad Laboratories) was performed according to the manufacturer's instructions. Primer sequences and melting temperatures are summarized in Table 1. 
Table 1 Quantitative RT-PCR primer sequences used in this study

\begin{tabular}{|c|c|c|c|c|}
\hline Primers & Sequences & Melting temp & Product size & Reference \\
\hline HBD1 Forward & 5'-CCCAGTTCCTGAAATCCTGA-3' & $56^{\circ} \mathrm{C}$ & $215 b p$ & (Han et al., 2008) [15] \\
\hline Reverse & 5'-CAGGTGCCTTGAATTTTGGT-3' & $56^{\circ} \mathrm{C}$ & & \\
\hline HBD3 Forward & 5'-AGCCTAGCAGCTATGAGGATC-3' & $56^{\circ} \mathrm{C}$ & $206 \mathrm{bp}$ & (Han et al., 2008) [15] \\
\hline Reverse & 5'-CTTCGGCAGCATTTTGCGCCA-3' & & & \\
\hline HBD5 Forward & 5'-TCCATCAGGTGAGTTTGCTG-3' & $57^{\circ} \mathrm{C}$ & $105 \mathrm{bp}$ & $(*)$ \\
\hline Reverse & 5'-GTTCAGCCTGCAATTTCCAT-3' & & & \\
\hline HBD8 Forward & 5'-TGCCTTGAAACAGAAATCCA-3' & $56^{\circ} \mathrm{C}$ & $104 \mathrm{bp}$ & $(* *)$ \\
\hline Reverse & 5'-TCCTIITGGGGTGTAGTGCTC -3' & & & \\
\hline HBD9 Forward & 5'-GGCCTAAATCCAGGTGTGAA-3' & $57^{\circ} \mathrm{C}$ & $174 b p$ & (Alekseeva et al., 2009) [33] \\
\hline Reverse & 5'-TCAAATGTTGGCAAGTGGAG-3' & & & \\
\hline HBD18 Forward & 5'-TGCATTCCATCCAATGAAGA-3' & $57^{\circ} \mathrm{C}$ & $181 \mathrm{bp}$ & $(* * *)$ \\
\hline Reverse & 5'-GAGGTCTCAGTTCCCCTTCC-3' & & & \\
\hline LL-37 Forward & 5'-CTAGAGGGAGGCAGACATGG-3' & $57^{\circ} \mathrm{C}$ & $201 \mathrm{bp}$ & (Amer, Bishop, \& van Hoek, 2010) [32] \\
\hline Reverse & 5'-AGGAGGCGGTAAGGTTAGC-3' & & & \\
\hline
\end{tabular}

This table summarizes the primers that were used in this study, the melting temperature, the predicted product size and relevant references. Invitrogen OligoPerfect ${ }^{\mathrm{TM}}$ Designer was used to design new primers. $\left(^{*}\right)$ NM_152250.1 Homo sapiens defensin, beta 105A (DEFB105A), mRNA; $\left(^{* *}\right)$ NM_001002035.1 Homo sapiens defensin, beta 108B (DEFB108B), mRNA; $\left.{ }^{* * *}\right)$ NM_054112.2 Homo sapiens defensin, beta 118 (DEFB118), mRNA.

\section{Immunofluorescence}

A549 cells were grown on chambered slides (BD Falcon, 354108) and exposed to CSE as above for $\beta$-defensin induction. Cells were fixed, permeabilized and blocked as previously described [34], and a 1:500 dilution of anti-human $\beta$-defensin primary antibody (Abcam, ab14421 Anti-beta Defensin 1 antibody, ab19270 Anti-beta 3 Defensin antibody, ab70215 Anti-beta 4 Defensin antibody) was applied for $1 \mathrm{hr}$. Detection was performed with 1:5000 dilution of secondary antibody labeled with Alexafluor 488 (Green), using ProLong Gold anti-fade with DAPI (Blue). Images were obtained as previously described [34], using the Nikon Confocal microscope.

\section{Statistical analysis}

Statistical analysis and graphing was carried out using Prism 5 software (GraphPad, La Jolla, CA). The two-tailed t-test assuming unequal variance was used to compare negative control $\beta$-defensin gene expression of the two different experimental groups expression profiles (IL-1 $\beta$, cigarette smoke extract, CSE) compared to the control (DMSO alone).

\section{Ethical \& safety approvals}

All experiments were approved by the Institutional Review Board at George Mason University. Since only a commercially available, de-identified human cell line was used, no ethical approvals were required for this research.

\section{Results}

Based on emerging reports of potentially important roles for some of the newly discovered human $\beta$-defensins in lung defense (hBD3, hBD5, hBD8, hBD9, hBD18) $[18,24,33]$, and the emerging role of hBD1 in COPD [11], we chose to study this selected set of the human $\beta$-defensin genes that had not been previously examined for their alteration following exposure to cigarette smoke (CSE) $[29,35]$. We included the human cathelicidin, LL-37/CAMP, as a comparator, as it also is thought to play a significant role in lung defense [17].

\section{HBD1}

The first identified human $\beta$-defensin gene, hBD1, is considered a constitutively produced antimicrobial peptide, whose expression has not been observed to change significantly under physiological conditions [36,37]. Following treatment with $50 \mu \mathrm{g} / \mathrm{ml}$ cigarette smoke (CSE), there is no significant change in hBD1 expression $($ Control $=1.000+/-0.324, \mathrm{CSE}=0.643+/-0.046, \mathrm{p}>0.05)$ compared to mock treated cells. This confirms previous findings, as the expression of this peptide is also not up-regulated by $10 \mathrm{ng} / \mathrm{ml}$ of IL- $1 \beta$ treatment (IL- $1 \beta=$ $1.123+/-0.086)(\mathrm{n}=3)$ compared to mock treated cells (Figure 1A).

\section{HBD3, hBD5 and hBD9}

The human $\beta$-defensins hBD3, hBD5 and hBD9 were found to be significantly increased following treatment with $50 \mu \mathrm{g} / \mathrm{ml}$ cigarette smoke extract (CSE) when compared to mock treated cells, and induced as much as with $10 \mathrm{ng} / \mathrm{ml}$ of $\mathrm{IL}-1 \beta$ treatment. In response to CSE, hBD3 was 7.95 fold increased ( $\mathrm{p}=0.032)$, hBD5 was 2.8 fold increased $(\mathrm{p}=0.0083)$ and hBD9 was 4.2 fold increased $(\mathrm{p}=0.0078)$. $(\mathrm{n}=3$ for hBD3, $9, \mathrm{n}=6$ for hBD5) (Figure $1 \mathrm{~B})$. 


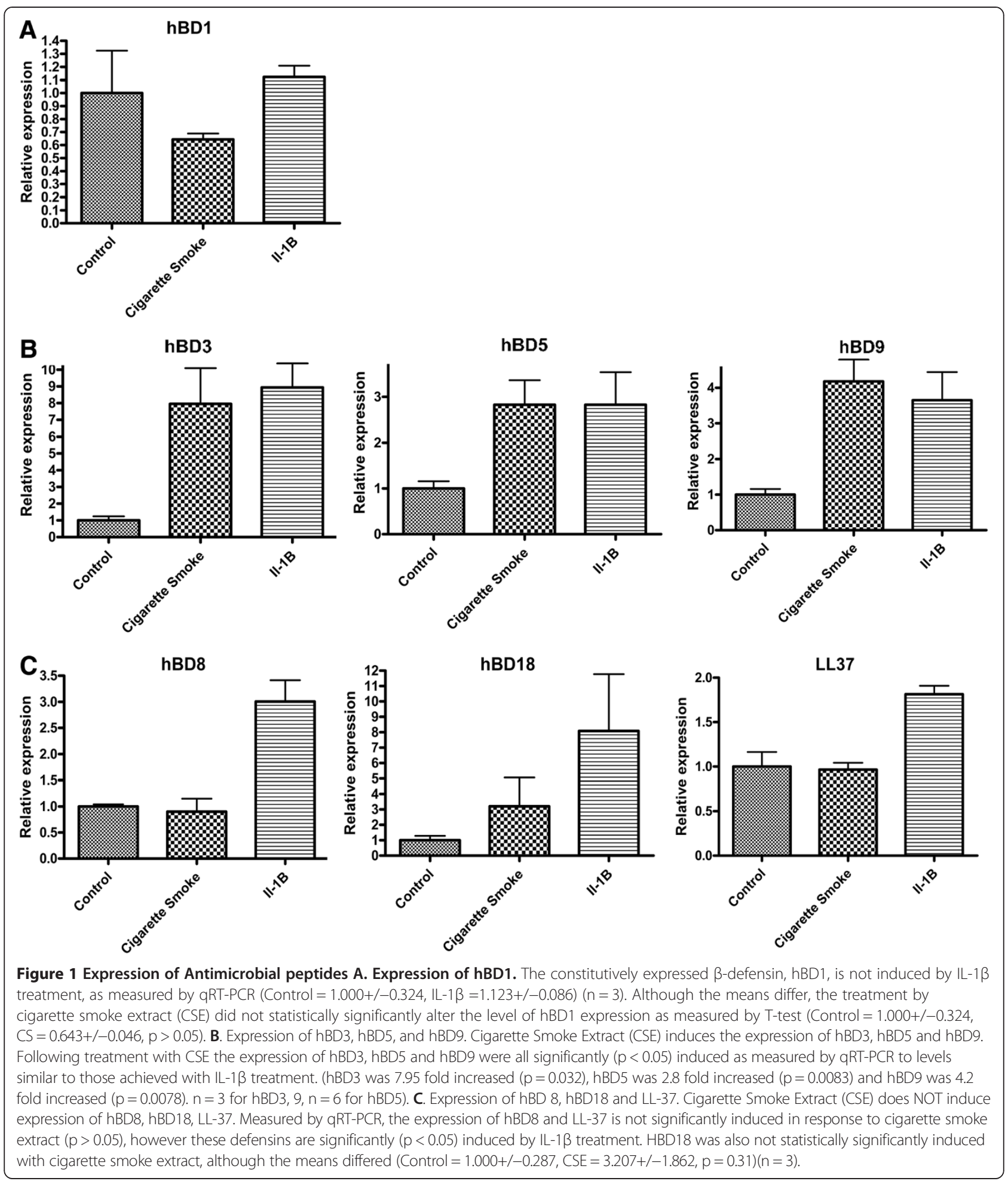

\section{HBD8 and hBD18}

Expression of the antimicrobial peptide gene hBD8 was not significantly induced in response to $50 \mu \mathrm{g} / \mathrm{ml}$ cigarette smoke extract (CSE) ( $p>0.05)$, however this $\beta$-defensin is significantly $(\mathrm{p}<0.05)$ induced by $10 \mathrm{ng} / \mathrm{ml}$ of IL- $1 \beta$ treatment. The expression of another $\beta$-defensin peptide gene hBD18 was not statistically significantly induced with $50 \mu \mathrm{g} / \mathrm{ml}$ cigarette smoke extract, although the means differed $($ Control $=1.000+/-0.287, \quad$ CSE $=3.207+/-1.862)$ $(\mathrm{p}=0.31)$. (Figure 1C). 


\section{A.}

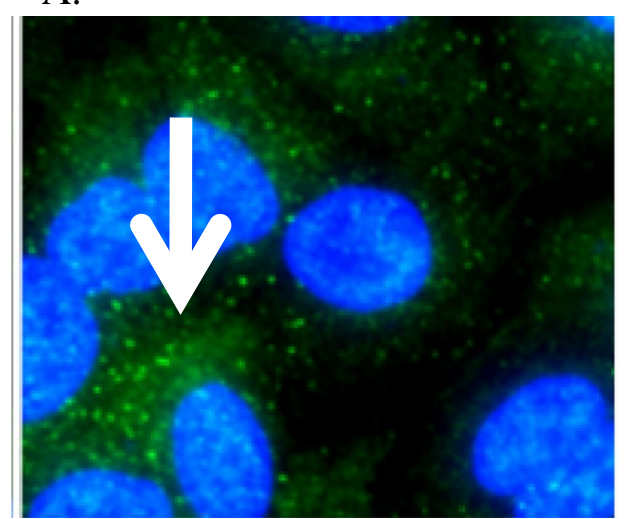

human $\beta$-defensin 3
B.

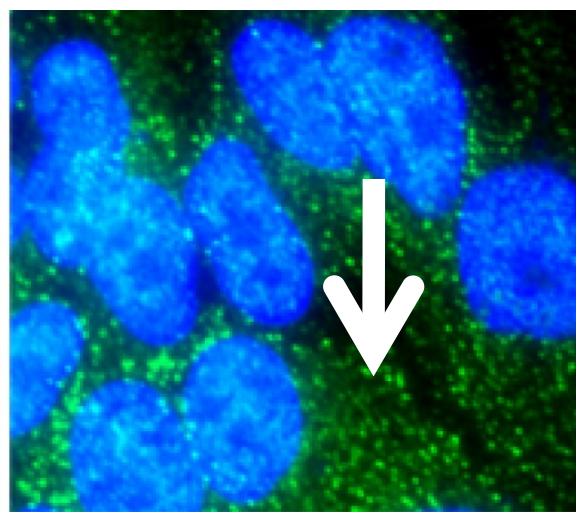

human $\beta$-defensin 4

Figure 2 Immunofluorescence Microscopy of hBDs in A549 cells treated with cigarette smoke extract. Green = human $\beta$-defensin (Alexafluor 488), Blue = nuclei (DAPI). A. hBD3 protein is observed in punctate staining in A549 cells (White arrow points to punctate staining). B. hBD4 protein is observed in heavily punctate staining in A549 cells (White arrow points to punctate staining).

\section{LL-37}

Expression of the cathelicidin gene LL-37 was not significantly induced in response to $50 \mu \mathrm{g} / \mathrm{ml}$ cigarette smoke extract (CSE) ( $p>0.05)$ either, however this antimicrobial peptide gene is significantly $(\mathrm{p}<0.05)$ induced by $10 \mathrm{ng} / \mathrm{ml}$ of IL-1 $\beta$ treatment. (Figure $1 C$ ).

\section{Visualization of hBDs by fluorescent microscopy}

A549 cells exposed to $50 \mu \mathrm{g} / \mathrm{ml}$ cigarette smoke (CSE) and processed in situ displayed positive staining for the internal presence of human $\beta$-defensins (Figure 2). Immunofluorescent microscopy was performed of cigarettesmoke treated A549 cells staining for hBD1, hBD3, and hBD4. Shown are representative images of staining for hBD3 and hBD4 peptides. No differential defensin staining was observed in the cells for hBD1 (data not shown), suggesting a similar result as was shown by the lack of induction of hBD1 seen in the qRT-PCR study.

\section{Discussion}

A549 cells are considered to be a cell-line model for Type II alveolar epithelial cells, which secrete the lung surfactant and A549 express some of the markers of Type II cells $[38,39]$. In this study, we use the A549 cell model to measure relative gene expression of two classes of AMP; human $\beta$-defensins (hBDs) and the human cathelicidin (LL-37) in response to exposure to cigarette smoke extract. Total RNA was extracted from the samples and quantitative real-time PCR was performed to quantify AMP gene expression using gene specific primers.

The experimental approach was to expose A549 cells to $50 \mu \mathrm{g} / \mathrm{ml}$ cigarette smoke extract (dissolved in DMSO), compared to control cells treated with DMSO alone. The positive control cells were exposed to $10 \mathrm{ng} / \mathrm{ml}$
IL-1 $\beta$ which is known to up-regulate the expression of many defensin peptides [33]. The mRNA was then prepared from all samples, and qRT-PCR was performed for hBD1, hBD3, hBD5, hBD8, hBD9, hBd18, and the Cathelicidin LL-37. Overall, the application of $10 \mathrm{ng} / \mathrm{ml}$ IL-1 $\beta$ to A549 cells induced the expression of most of the tested human $\beta$-defensins (except hBD1, see below), confirming that the cells responded to the stimuli as expected.

We found that hBD3, hBD5, and hBD9 gene expression was up-regulated in A549 cells exposed to $50 \mu \mathrm{g} / \mathrm{ml} \mathrm{CSE}$, while hBD1, hBD8, hBD18 and LL-37 gene expression did not significantly change. Expression of hBD1, hBD3 and hBD4 peptides within the A549 cells (in situ) was visualized by IF. This differential expression suggests that hBD3, hBD5, and hBD9 may play a role in the changes to the lung tissue observed in smokers. Establishing the differential human $\beta$-defensin gene expression following CSE treatment will add to our understanding of the molecular response of the lung alveolar epithelium to cigarette smoke exposure.

Our data demonstrates the differential induction of expression of specific $\beta$-defensin peptide genes as a result of exposure to cigarette smoke extract and suggests that three $\beta$-defensin genes (hBD3, hBD5, hBD9) may represent biomarkers of cigarette smoke extract exposure for alveolar epithelial cells [40-46]. These findings may contribute to a greater understanding of the role of the newly identified $\beta$-defensin peptides in the response of lung epithelial cells to cigarette-smoke. Further studies of other sample types from smokers, such as bronchoalveolar lavage could be used to validate these findings. Such biomarkers may have utility in studying the recovery of lung cells following the cessation of smoking. 
Gene expression for hBD1 was not changed by exposure to cigarette smoke or IL-1 $\beta$, as expected. The expression of hBD5, hBD8, hBD9 and hBD18, four of the new members of the human $\beta$-defensin gene family, are inducible by IL-1 $\beta$ in A549 lung epithelial cells, indicating they may respond to IL-1 $\beta$ regulation in vivo and may be involved in inflammatory responses and cell proliferation, differentiation, and apoptosis. Three genes, hBD8, hBD18 and the cathelicidin LL-37, were induced with IL-1 $\beta$ treatment, but not with cigarette smoke treatment, suggesting there is specificity of regulation for the different $\beta$-defensins. hBD3, hBD5, and hBD9 gene expression was increased by cigarette smoke extract treatment to the same extent as with IL- $1 \beta$ treatment. This suggests that these three $\beta$-defensins may have similar regulation by components of the cigarette smoke extract. Similarly, differentially-regulated expression of hBD3 and hBD9 was observed in infectious keratitis of the human eye [47] supporting that differential regulation of human $\beta$-defensin gene expression can occur. HBD3 is thought to be an important component of lung defense, such as in response to Legionella infection [48].

Exposure to cigarette smoke is thought to be harmful to host respiratory defenses through multiple modes of action [8]. Recent studies have suggested that cigarette smoke alters the production of hBD2 [28,29,49-54]. The induction of hBD2 and hBD3 expression (as well as IL-1B) in human gingival epithelial cells by cigarette smoke is thought to be through the activation of ERK1/2 and NF-kB pathways [30]. Nictotine has been reported to upregulate the expression of hBD2 via a p38 MAPK dependent pathway in human keratinocytes [55]. Cigarette smoke contains many toxic components, including potentially bacterial lipopolysaccharides [56], which in combination with the delivered nicotine could contribute to these observed effects of cigarette smoke. HBD2 is expressed in keratinocytes, the gingival mucosa and the tracheal epithelium [48,57-59] and alteration of its gene expression has been found in many diseases, such as infectious diseases, CF, and lupus erythematosus [60].

$\mathrm{Xu}$ recently showed that cigarette smoke extract significantly increased the production of IL-1 $\beta$ [57]. It was also shown that cigarette smoke inhibits the subsequent induction of hBD2 expression in response to bacterial lipopolysaccharide [52] or IL-1 $\beta$ [51], suggesting that cigarette smoke also may suppress the normal host defense response to bacterial pathogen exposure in the lung [35]. Kanda et al. recently demonstrated that exposure to hBD2 enhanced mRNA levels and secretion of many cytokines, including IL-1 $\beta$ [58]. Therefore, cigarette smoke may directly stimulate novel hBD production, leading to enhancement of IL-1 $\beta$, which in turn could further stimulate additional hBD production, in a paracrine or autocrine loop. Interestingly, Kanda also reported that the effects of hBD2 were counteracted by the drug Pentoxifylline (PTX) [58]. PTX is a drug with strong anti-inflammatory properties. This observation suggests that we should investigate the ability of PTX to potentially counteract the effect of chronic CSE-induced overexpression of human $\beta$-defensins.

Stimulation of oral squamous cell carcinoma (BHYOSCC) cell line with hBD1 results in reduction of cell proliferation, whereas hBD2 and hBD3 stimulation causes promotion of cell proliferation, indicating that hBD2 and hBD3 might be protooncogenes in OSCCs [59]. Recent studies demonstrated all lung tumor samples, independent of their histological type, express hBD2 peptide, and its expression levels correlates with the differentiation grade of lung adenocarcinoma [61], suggesting that the role of human $\beta$-defensins in lung cancer should be further investigated also.

The health effects of cigarette smoke on lung health are significant. Establishing a link between smoking and the induction of novel and established antimicrobial peptides is an important step in understanding the pathology observed in cigarette smokers. AMPs may represent novel biomarkers of overall lung cell health status, as well as having potential direct effects in the pathogenesis of cigarette smoking. In the long term, we would like to investigate whether chronic antimicrobial peptide induction may contribute to lung pathology, which may occur before the occurrence of cancer or Chronic Obstructive Pulmonary Disease (COPD). If so, AMP induction could potentially be useful as both a biomarker of cigarette exposure, as well as a possible target for therapeutic intervention.

\section{Abbreviations \\ CSE: Cigarette smoke extract; HBD: Human beta-defensin; BALF: Bronchiolar lavage fluid; TNF-a: Tumor necrosis factor alpha; TLR: Toll-like receptor; CF: Cystic fibrosis; COPD: Chronic obstructive pulmonary disease; PCR: Polymerase chain reaction; IF: Immunofluorescence; DMSO: Dimethly sulfoxide; mRNA: messenger ribonucleic acid; DAPI: 4',6-diamidino-2-phenylindole; IL-1ß: Interleukin-1 beta; LPS: Lipopolysaccharide.}

\section{Competing interest}

The authors declare that they have no competing interest.

\section{Authors' contributions}

MVH conceived and designed the study. TP helped to design the study, performed key experiments and did data analysis. MVH and TP co-wrote the manuscript. SLP and DP performed some qRT-PCR experiments and contributed to the data analysis. All authors read and approved the final manuscript.

\section{Acknowledgements}

We thank SuHua Han for technical assistance with the qRT-PCR. This work was partially supported by a grant from Mason INOVA Life Sciences Research Fund, SigmaXi Grant-in-Aid of Research to TP, and the GMU Provost Summer Research Award to MVH. TP and SLP were supported by the Long Term Health Education and Training program of the US Army. MVH was partially supported by "Infectious Disease Proteome Biomarkers", DE-FC52

-04NA25455, U.S. Department of Energy. This work was also partially supported by DTRA project "HDTRA1-12-C-0039 Translational Peptide Research for Personnel Protection". 


\section{Author details}

${ }^{1}$ School of Systems Biology, George Mason University, Manassas, VA, USA ${ }^{2}$ National Center for Biodefense and Infectious Diseases, George Mason University, Manassas, VA, USA. ${ }^{3}$ Discovery Hall, George Mason University, 10910 University Blvd, MS1H8, Manassas, VA 20120, USA.

Received: 4 February 2013 Accepted: 12 April 2013

Published: 29 April 2013

\section{References}

1. Doll R: Uncovering the effects of smoking: historical perspective. Stat Methods Med Res 1998, 7(2):87-117.

2. Sangodkar J, et al: Lung adenocarcinoma: lessons in translation from bench to bedside. Mt Sinai J Med 2010, 77(6):597-605.

3. Brusselle GG, Joos GF, Bracke KR: New insights into the immunology of chronic obstructive pulmonary disease. Lancet 2011, 378(9795):1015-1026.

4. McMaster SK, et al: Cigarette smoke inhibits macrophage sensing of Gram-negative bacteria and lipopolysaccharide: relative roles of nicotine and oxidant stress. Br J Pharmacol 2008, 153(3):536-543

5. Kier LD, Yamasaki $E$, Ames BN: Detection of mutagenic activity in cigarette smoke condensates. Proc Natl Acad Sci U S A 1974, 71(10):4159-4163.

6. Smith CJ, et al: IARC carcinogens reported in cigarette mainstream smoke and their calculated log P values. Food Chem Toxicol 2003, 41(6):807-817.

7. Shin $\mathrm{HJ}$, et al: Effect of cigarette filters on the chemical composition and in vitro biological activity of cigarette mainstream smoke. Food Chem Toxicol 2009, 47(1):192-197.

8. Nikota JK, Stampfli MR: Cigarette smoke-induced inflammation and respiratory host defense: Insights from animal models. Pulm Pharmacol Ther 2012, 25(4):257-262

9. Dwyer TM: Cigarette smoke-induced airway inflammation as sampled by the expired breath condensate. Am J Med Sci 2003, 326(4):174-178.

10. Doss $M$, et al: Human defensins and LL-37 in mucosal immunity. J Leukoc Biol 2010, 87(1):79-92.

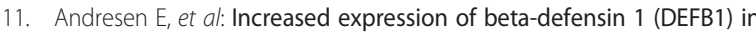
chronic obstructive pulmonary disease. PLoS One 2011, 6(7):e21898.

12. Liao Z, et al: Enhanced expression of human beta-defensin 2 in peripheral lungs of patients with chronic obstructive pulmonary disease. Peptides 2012, 38(2):350-356.

13. Janssens W, et al: Genomic copy number determines functional expression of beta-defensin 2 in airway epithelial cells and associates with chronic obstructive pulmonary disease. Am J Respir Crit Care Med 2010, 182(2):163-169.

14. Matsushita I, et al: Genetic variants of human beta-defensin-1 and chronic obstructive pulmonary disease. Biochem Biophys Res Commun 2002, 291(1):17-22.

15. Han S, Bishop BM, van Hoek ML: Antimicrobial activity of human betadefensins and induction by Francisella. Biochem Biophys Res Commun 2008, 371(4):670-674.

16. Swain RJ, et al: Assessment of cell line models of primary human cells by Raman spectral phenotyping. Biophys J 2010, 98(8):1703-1711.

17. Hiemstra PS: Defensins and cathelicidins in inflammatory lung disease: beyond antimicrobial activity. Biochem Soc Trans 2006, 34(Pt 2):276-278.

18. Schutte $B C$, et al: Discovery of five conserved beta -defensin gene clusters using a computational search strategy. Proc Natl Acad Sci U S A 2002, 99(4):2129-2133

19. Rodriquez-Jimenez FJ, et al: Distribution of new human beta-defensin genes clustered on chromosome 20 in functionally different segments of epididymis. Genomics 2003, 81(2):175-183.

20. Yamaguchi $Y$, Ouchi $Y$ : Antimicrobial peptide defensin: identification of novel isoforms and the characterization of their physiological roles and their significance in the pathogenesis of diseases. Proc Jpn Acad Ser B Phys Biol Sci 2012, 88(4):152-166.

21. Garcia JR, et al: Identification of a novel, multifunctional beta-defensin (human beta-defensin 3) with specific antimicrobial activity. Its interaction with plasma membranes of Xenopus oocytes and the induction of macrophage chemoattraction. Cell Tissue Res 2001, 306(2):257-264.

22. Garcia JR, et al: Human beta-defensin 4: a novel inducible peptide with a specific salt-sensitive spectrum of antimicrobial activity. FASEB J 2001, 15(10):1819-1821.
23. Vareille $M$, et al: The airway epithelium: soldier in the fight against respiratory viruses. Clin Microbiol Rev 2011, 24(1):210-229.

24. Kao CY, et al: ORFeome-based search of airway epithelial cell-specific novel human beta-defensin genes. Am J Respir Cell Mol Biol 2003, 29(1):71-80.

25. Weinberg A, et al: The yin and yang of human Beta-defensins in health and disease. Front Immunol 2012, 3:294

26. Domagala-Kulawik J: Effects of cigarette smoke on the lung and systemic immunity. J Physiol Pharmacol 2008, 59(Suppl 6):19-34.

27. Chen $X$, et al: Antimicrobial peptides human beta-defensin (hBD)-3 and hBD-4 activate mast cells and increase skin vascular permeability. Eur J Immunol 2007, 37(2):434-444.

28. Chen $\mathrm{L}$, et al: Cigarette smoke enhances beta-defensin 2 expression in rat airways via nuclear factor-kappaB activation. Eur Respir J 2010, 36(3):638-645

29. Mahanonda $\mathrm{R}$, et al: Cigarette smoke extract modulates human beta-defensin-2 and interleukin-8 expression in human gingival epithelial cells. J Periodontal Res 2009, 44(4):557-564.

30. Semlali A, et al: Whole cigarette smoke increased the expression of TLRs, HBDs, and proinflammory cytokines by human gingival epithelial cells through different signaling pathways. PLoS One 2012, 7(12):e52614

31. Kulkarni R, et al: Cigarette smoke inhibits airway epithelial cell innate immune responses to bacteria. Infect Immun 2010, 78(5):2146-2152.

32. Amer LS, Bishop BM, van Hoek ML: Antimicrobial and antibiofilm activity of cathelicidins and short, synthetic peptides against Francisella. Biochem Biophys Res Commun 2010, 396(2):246-251.

33. Alekseeva $L$, et al: Inducible expression of beta defensins by human respiratory epithelial cells exposed to Aspergillus fumigatus organisms. BMC Microbiol 2009, 9:33.

34. Pierson T, et al: Proteomic characterization and functional analysis of outer membrane vesicles of Francisella novicida suggests possible role in virulence and use as a vaccine. J Proteome Res 2011, 10(3):954-967.

35. Herr $C$, et al: Suppression of pulmonary innate host defence in smokers. Thorax 2009, 64(2):144-149.

36. O'Neil DA, et al: Expression and regulation of the human beta-defensins hBD-1 and hBD-2 in intestinal epithelium. J Immunol 1999, 163(12):6718-6724.

37. Eckmann L: Defence molecules in intestinal innate immunity against bacterial infections. Curr Opin Gastroenterol 2005, 21(2):147-151.

38. Andreeva AV, Kutuzov MA, Voyno-Yasenetskaya TA: Regulation of surfactant secretion in alveolar type II cells. Am J Physiol Lung Cell Mol Physiol 2007, 293(2):L259-L271.

39. Fehrenbach $\mathrm{H}$ : Alveolar epithelial type II cell: defender of the alveolus revisited. Respir Res 2001, 2(1):33-46.

40. Hsieh SJ, et al: Biomarkers increase detection of active smoking and secondhand smoke exposure in critically ill patients. Crit Care Med 2011, 39(1):40-45

41. Liu J, et al: Relationship between biomarkers of cigarette smoke exposure and biomarkers of inflammation, oxidative stress, and platelet activation in adult cigarette smokers. Cancer Epidemiol Biomarkers Prev 2011, 20(8):1760-1769.

42. Morin A, et al: Estimation and correlation of cigarette smoke exposure in Canadian smokers as determined by filter analysis and biomarkers of exposure. Regul Toxicol Pharmacol 2011, 61(3 Suppl):S3-S12.

43. Naufal ZS, et al: Differential exposure biomarker levels among cigarette smokers and smokeless tobacco consumers in the National Health and Nutrition Examination Survey 1999-2008. Biomarkers 2011, 16(3):222-235.

44. Sexton $\mathrm{K}$, et al: Proteomic profiling of human respiratory epithelia by iTRAQ reveals biomarkers of exposure and harm by tobacco smoke components. Biomarkers 2011, 16(7):567-576.

45. Yuchuan $\mathrm{H}$, et al: Circulating biomarkers of hazard effects from cigarette smoking. Toxicol Ind Health 2011, 27(6):531-535.

46. Bernert JT, et al: Increases in tobacco exposure biomarkers measured in non-smokers exposed to sidestream cigarette smoke under controlled conditions. Biomarkers 2009, 14(2):82-93.

47. Otri AM, et al: Variable expression of human Beta defensins 3 and 9 at the human ocular surface in infectious keratitis. Invest Ophthalmol Vis Sci 2012, 53(2):757-761.

48. Scharf $S$, et al: Legionella pneumophila induces human beta defensin-3 in pulmonary cells. Respir Res 2010, 11:93.

49. Gross CA, et al: Beta2-agonists promote host defense against bacteria infection in primary human bronchial epithelial cells. BMC Pulm Med 2010, 10:30. 
50. Liao Z, et al: Enhanced expression of human beta-defensin 2 in peripheral lungs of patients with chronic obstructive pulmonary disease. Peptides 2012, 38:350-356.

51. Pace $E$, et al: Beta defensin-2 is reduced in central but not in distal airways of smoker COPD patients. PLoS One 2012, 7(3):e33601.

52. Zhang W, et al: Cigarette smoke modulates PGE(2) and host defence against Moraxella catarrhalis infection in human airway epithelial cells. Respirology 2011, 16(3):508-516.

53. Shibata $Y$, et al: Altered expression of antimicrobial molecules in cigarette smoke-exposed emphysematous mice lungs. Respirology 2008, 13(7):1061-1065.

54. Yamin $\mathrm{M}$, et al: Cigarette smoke combined with Toll-like receptor 3 signaling triggers exaggerated epithelial regulated upon activation, normal T-cell expressed and secreted/CCL5 expression in chronic rhinosinusitis. J Allergy Clin Immunol 2008, 122(6):1145-1153 e3.

55. Nakamura $\mathrm{S}$, et al: Nicotine induces upregulated expression of beta defensin-2 via the p38MAPK pathway in the $\mathrm{HaCaT}$ human keratinocyte cell line. Med Mol Morphol 2010, 43(4):204-210.

56. Lee J, Taneja V, Vassallo R: Cigarette smoking and inflammation: cellular and molecular mechanisms. J Dent Res 2012, 91(2):142-149.

57. $\mathrm{Xu} \mathrm{J,} \mathrm{Xu} \mathrm{F,} \mathrm{Lin} \mathrm{Y:} \mathrm{Cigarette} \mathrm{smoke} \mathrm{synergizes} \mathrm{lipopolysaccharide-induced}$ interleukin-1 beta and tumor necrosis factor-alpha secretion from macrophages via substance P-mediated nuclear factor-kappaB activation. Am J Respir Cell Mol Biol 2011, 44(3):302-308.

58. Kanda N, et al: Human beta-defensin-2 enhances IFN-gamma and IL-10 production and suppresses IL-17 production in T cells. J Leukoc Biol 2011, 89(6):935-944.

59. Winter J, et al: Human beta-defensin-1, -2 , and -3 exhibit opposite effects on oral squamous cell carcinoma cell proliferation. Cancer Invest, 29(3):196-201

60. Kreuter A, et al: Expression of antimicrobial peptides in different subtypes of cutaneous lupus erythematosus. J Am Acad Dermatol 2011 , 65(1):125-133.

61. Shestakova T, et al: Immunohistochemical analysis of beta-defensin-2 expression in human lung tumors. Exp Oncol 2010, 32(4):273-276.

doi:10.1186/1617-9625-11-10

Cite this article as: Pierson et al:: Cigarette smoke extract induces differential expression levels of beta-defensin peptides

in human alveolar epithelial cells. Tobacco Induced Diseases 2013 11:10.

\section{Submit your next manuscript to BioMed Central and take full advantage of:}

- Convenient online submission

- Thorough peer review

- No space constraints or color figure charges

- Immediate publication on acceptance

- Inclusion in PubMed, CAS, Scopus and Google Scholar

- Research which is freely available for redistribution 